\title{
Strengthening and Westward Shift of the Tropical Pacific Walker Circulation during the Mid-Holocene: PMIP Simulation Results ${ }^{\mathfrak{a}}$
}

\author{
ZHIPING TIAN \\ Institute of Atmospheric Physics, Chinese Academy of Sciences, Beijing, China, and \\ International Pacific Research Center, School of Ocean and Earth Science \\ and Technology, University of Hawai' $i$ at Mānoa, \\ Honolulu, Hawaii
}

TIM LI

International Pacific Research Center, School of Ocean and Earth Science and Technology, University of Hawai' $i$ at Mānoa, Honolulu, Hawaii, and International Laboratory on Climate and Environment Change and Key Laboratory of Meteorological Disaster, Nanjing University of Information Science and Technology, Nanjing, China

\section{DABANG JIANG}

Institute of Atmospheric Physics, Chinese Academy of Sciences, Beijing, and International Laboratory on Climate and Environment Change and Key Laboratory of Meteorological Disaster, Nanjing University of Information Science and Technology, Nanjing, and CAS Center for Excellence in Tibetan Plateau Earth Sciences, Beijing, and Joint Laboratory for Climate and Environmental Change at Chengdu University of Information Technology, Chengdu, China

(Manuscript received 14 October 2016, in final form 22 November 2017)

\begin{abstract}
Based on the zonal mass streamfunction, the mid-Holocene annual and seasonal changes in the tropical Pacific Walker circulation (PWC) are examined using numerical simulations from the Paleoclimate Modelling Intercomparison Project Phases 2 and 3. Compared to the preindustrial period, the annual mean of the PWC intensity strengthened (with an average increase of $0.26 \times 10^{14} \mathrm{~kg}^{2} \mathrm{~m}^{-2} \mathrm{~s}^{-1}$ or $5 \%$ ), and both the western edge and center of the PWC cell shifted westward (by an average of $4^{\circ}$ and $3^{\circ}$, respectively) in the majority of the 29 models used for analysis during the midHolocene. Those changes were closely related to an overall increase in the equatorial Indo-Pacific east-west sea level pressure difference and low-level trade winds over the equatorial Pacific. Annual mean PWC changes come mainly from boreal warm seasons. In response to the mid-Holocene orbital forcing, Asian and North African monsoon rainfall was strengthened due to large-scale surface warming in the Northern Hemisphere in boreal warm seasons, which led to an intensified large-scale thermally direct east-west circulation, resulting in the enhancement and westward shift of the tropical PWC. The opposite occurred during the mid-Holocene boreal cold seasons. Taken together, the change in the monsoon rainfall over the key tropical regions of Asia and North Africa and associated large-scale east-west circulation, rather than the equatorial Pacific SST change pattern, played a key role in affecting the mid-Holocene PWC strength.
\end{abstract}

\section{Introduction}

The tropical Pacific Walker circulation (PWC), a planetary-scale east-west overturning atmospheric

Supplemental information related to this paper is available at the Journals Online website: https://doi.org/10.1175/JCLI-D-160744.s1.

Corresponding author: Zhiping Tian, tianzhiping@mail.iap.ac.cn circulation in the equatorial belt with ascending motion over the Maritime Continent and western Pacific and descending motion over the eastern Pacific, is an important component of the global climate system (Bjerknes 1969). Its variations are closely linked to those of El Niño-Southern Oscillation (ENSO) (Julian and Chervin 1978; Philander 1990) and monsoonal circulations over adjacent continents (Webster et al. 1998; Tanaka et al. 2004), and long-term changes in its intensity and structure affect climate across the globe 
(Deser and Wallace 1990). Understanding the tropical PWC change is therefore of broad scientific and socioeconomic interest.

Long-term changes in PWC under global warming have been extensively studied based on observations and numerical simulations, which have yielded conflicting results regarding whether the PWC trends during the twentieth century have weakened (Tanaka et al. 2004; Vecchi et al. 2006; Vecchi and Soden 2007; DiNezio et al. 2009, 2013; Power and Kociuba 2011; Tokinaga et al. 2012a,b; Kociuba and Power 2015), strengthened (Sohn and Park 2010; Luo et al. 2012; Meng et al. 2012; Wang et al. 2012; L'Heureux et al. 2013; Sohn et al. 2013; Sandeep et al. 2014; Li et al. 2015; Ma and Zhou 2016), or remained unchanged (Compo et al. 2011). The uncertainties primarily arise from the difference between the observational datasets (Deser et al. 2010) and different time periods used for analysis, as natural variability accounts for much of the variation on multidecadal scales and longer $(\sim 100 \mathrm{yr})$ intervals are likely more associated with external forced climate change (L'Heureux et al. 2013). This remains an important issue for future climate change, among which the twenty-first-century PWC tends to weaken but displays low credibility in model projections (Power and Kociuba 2011; Kociuba and Power 2015). Moreover, mechanisms of the long-term changes in PWC, including homogeneous warming mechanisms associated with the global mean rainfall-moisture relationship (Knutson and Manabe 1995; Held and Soden 2006; Gastineau et al. 2009) and inhomogeneous warming mechanisms dominated by tropical Pacific sea surface temperature (SST) change patterns (DiNezio et al. 2009, 2010; Tokinaga et al. 2012b; Sandeep et al. 2014), remain inconclusive. Nevertheless, model simulations under different external forcing conditions help unveil key physical processes. Since the tropical PWC oscillates with different mechanisms on orbital-to-decadal time scales, it is of importance to look back into the past for a better understanding of the PWC changes under different climate background states, and to examine whether the above uncertainties for present and future climates exist in past climate.

Paleoclimate modeling provides an opportunity to test the model sensitivity in response to external orbital forcing. The mid-Holocene, approximately 6000 years before present, is an ideal time period for such a study to understand past climate change on the orbital scale, because its climate was remarkably different from today and because natural forcings and paleodata are relatively well known (Joussaume and Taylor 1995; Braconnot et al. 2012a). The mid-Holocene is also one of the benchmark periods under the protocol of the Paleoclimate Modelling Intercomparison Project (PMIP), which offers the possibility of studying the climate response to changes in the orbital forcing. A hierarchy of simulations of the mid-Holocene tropical climate have been performed using coupled models (e.g., Bush 1999; Clement et al. 2000; Liu et al. 2000; Kitoh and Murakami 2002; Otto-Bliesner et al. 2003; Zhao et al. 2007; Brown et al. 2008; Zheng et al. 2008; Chiang et al. 2009; Zhou and Zhao 2010, 2013; Braconnot et al. 2012b; An and Choi 2014; Roberts et al. 2014; Tian et al. 2017), which show that although there are differences among simulations, most of the models can capture the large-scale features of the tropical climate, including the weakened ENSO activity. Previous studies have also shown that climate models generally reproduce strengthened monsoons and increased precipitation in North Africa and Asia (e.g., Anderson et al. 1988; Kutzbach and Liu 1997; Joussaume et al. 1999; Wang 1999; Braconnot et al. 2000; Bosmans et al. 2012; Jiang et al. 2013, 2015; Zheng et al. 2013) and North America (Harrison et al. 2003) during the midHolocene summer. Comparatively, only a few modeling studies have involved changes in the tropical PWC during the mid-Holocene with a lack of explicit investigation (e.g., Kitoh and Murakami 2002). Moreover, the mechanism responsible for the past PWC change remains unclear. Therefore, it is of particular interest to examine what the tropical PWC was like during that period in simulations with state-of-the-art climate models, and how the PWC variations are linked to the changes in ENSO and the adjacent continental monsoon circulations. Understanding the mid-Holocene changes in the tropical PWC and the underlying mechanism will thus shed some light on the long-term PWC changes under different climate backgrounds. This is the central motivation of this study.

Based on the above and considering the important role of ocean dynamics in the tropical climate, this paper presents an analysis of the mid-Holocene tropical PWC from the perspective of multiple coupled climate models in the framework of the PMIP Phases 2 (PMIP2) and 3 (PMIP3). We address the following questions: 1) Are PMIP2/3 simulations able to reproduce the modern key PWC characteristics in the tropics? 2) How does annual and seasonal tropical PWC respond to the mid-Holocene forcing? 3) What are the mechanisms involved in the most common changes among the models?

\section{Data and method}

\section{a. Model description}

The present study used all of the available models under the PMIP2/3 protocol for the mid-Holocene climate simulations, including 15 PMIP2 atmosphereocean or atmosphere-ocean-vegetation coupled models 
TABLE 1. Basic information about the climate models and their experiments used in this study. (Expansions of acronyms are available online at http://www.ametsoc.org/PubsAcronymList.)

\begin{tabular}{|c|c|c|c|c|c|c|c|}
\hline \multirow{2}{*}{\multicolumn{2}{|c|}{ Model ID }} & \multirow[b]{2}{*}{ Country } & \multirow[b]{2}{*}{ Atmospheric resolution } & \multicolumn{2}{|c|}{ Length of run analyzed (yr) } & \multirow{2}{*}{$\begin{array}{l}\text { No data for } \\
\text { vertical wind }\end{array}$} & \multirow{2}{*}{$\begin{array}{l}\text { No data } \\
\text { for SST }\end{array}$} \\
\hline & & & & Preindustrial & Mid-Holocene & & \\
\hline \multicolumn{8}{|c|}{ Fifteen coupled models within PMIP2 } \\
\hline 01 & CCSM3.0 & United States & $\sim 2.8^{\circ} \times 2.8^{\circ}, \mathrm{L} 18$ & 50 & 50 & & \\
\hline 02 & CSIRO-Mk3L-1.0 & Australia & $\sim 5.6^{\circ} \times 3.2^{\circ}, \mathrm{L} 18$ & 1000 & 1000 & $\sqrt{ }$ & \\
\hline 03 & CSIRO-Mk3L-1.1 & Australia & $\sim 5.6^{\circ} \times 3.2^{\circ}, \mathrm{L} 18$ & 1000 & 1000 & $\sqrt{ }$ & \\
\hline 04 & FGOALS-1.0g & China & $\sim 2.8^{\circ} \times 3^{\circ}-6^{\circ}$, L9 & 100 & 100 & & \\
\hline 05 & FOAM & United States & $7.5^{\circ} \times \sim 4.4^{\circ}, \mathrm{L} 18$ & 100 & 100 & & \\
\hline 06 & FOAM-gvm & United States & $7.5^{\circ} \times \sim 4.4^{\circ}, \mathrm{L} 18$ & 100 & 100 & & \\
\hline 07 & GISS ModelE & United States & $5^{\circ} \times 4^{\circ}, \mathrm{L} 17$ & 50 & 50 & & \\
\hline 08 & IPSL-CM4-V1-MR & France & $3.75^{\circ} \times \sim 2.5^{\circ}, \mathrm{L} 19$ & 100 & 100 & & \\
\hline 09 & MIROC3.2 & Japan & $\sim 2.8^{\circ} \times 2.8^{\circ}, \mathrm{L} 20$ & 100 & 100 & & \\
\hline 10 & MRI-CGCM2.3.4fa & Japan & $\sim 2.8^{\circ} \times 2.8^{\circ}, \mathrm{L} 30$ & 150 & 150 & & \\
\hline 11 & MRI-CGCM2.3.4fa-gvm & Japan & $\sim 2.8^{\circ} \times 2.8^{\circ}, \mathrm{L} 30$ & 100 & 100 & & \\
\hline 12 & MRI-CGCM2.3.4nfa & Japan & $\sim 2.8^{\circ} \times 2.8^{\circ}, \mathrm{L} 30$ & 150 & 150 & & \\
\hline 13 & MRI-CGCM2.3.4nfa-gvm & Japan & $\sim 2.8^{\circ} \times 2.8^{\circ}, \mathrm{L} 30$ & 100 & 100 & & \\
\hline 14 & UBRIS-HadCM3M2 & United Kingdom & $3.75^{\circ} \times 2.5^{\circ}, \mathrm{L} 19$ & 100 & 100 & $\sqrt{ }$ & \\
\hline 15 & UBRIS-HadCM3M2-gvm & United Kingdom & $3.75^{\circ} \times 2.5^{\circ}, \mathrm{L} 19$ & 100 & 100 & $\sqrt{ }$ & \\
\hline \multicolumn{8}{|c|}{ Fourteen coupled models within PMIP3 } \\
\hline 16 & BCC-CSM1.1 & China & $\sim 2.8^{\circ} \times 2.8^{\circ}, \mathrm{L} 26$ & 500 & 100 & & \\
\hline 17 & CCSM4 & United States & $1.25^{\circ} \times \sim 0.9^{\circ}, \mathrm{L} 26$ & 1051 & 301 & & \\
\hline 18 & CNRM-CM5 & France & $\sim 1.4^{\circ} \times 1.4^{\circ}, \mathrm{L} 31$ & 850 & 200 & & \\
\hline 19 & CSIRO-Mk3.6.0 & Australia & $1.875^{\circ} \times \sim 1.9^{\circ}, \mathrm{L} 18$ & 500 & 100 & & \\
\hline 20 & CSIRO-Mk3L-1.2 & Australia & $\sim 5.6^{\circ} \times 3.2^{\circ}, \mathrm{L} 18$ & 1000 & 500 & $\sqrt{ }$ & \\
\hline 21 & FGOALS-g2 & China & $\sim 2.8^{\circ} \times 3^{\circ}-6^{\circ}, \mathrm{L} 26$ & 900 & 100 & & $\sqrt{ }$ \\
\hline 22 & FGOALS-s2 & China & $\sim 2.8^{\circ} \times 1.7^{\circ}, \mathrm{L} 26$ & 501 & 100 & & $\sqrt{ }$ \\
\hline 23 & GISS-E2-R & United States & $2.5^{\circ} \times 2^{\circ}, \mathrm{L} 40$ & 1200 & 100 & & \\
\hline 24 & HadGEM2-CC & United Kingdom & $1.875^{\circ} \times 1.25^{\circ}, \mathrm{L} 60$ & 240 & 35 & $\sqrt{ }$ & \\
\hline 25 & HadGEM2-ES & United Kingdom & $1.875^{\circ} \times 1.25^{\circ}, \mathrm{L} 38$ & 576 & 102 & $\sqrt{ }$ & \\
\hline 26 & IPSL-CM5A-LR & France & $3.75^{\circ} \times \sim 1.9^{\circ}$, L39 & 1000 & 500 & & \\
\hline 27 & MIROC-ESM & Japan & $\sim 2.8^{\circ} \times 2.8^{\circ}, \mathrm{L} 80$ & 630 & 100 & & $\sqrt{ }$ \\
\hline 28 & MPI-ESM-P & Germany & $1.875^{\circ} \times \sim 1.9^{\circ}, \mathrm{L} 47$ & 1156 & 100 & & \\
\hline 29 & MRI-CGCM3 & Japan & $1.125^{\circ} \times \sim 1.1^{\circ}, \mathrm{L} 48$ & 500 & 100 & & \\
\hline
\end{tabular}

and 14 PMIP3 state-of-the-art coupled models that have overall higher spatial resolutions than the previous generation. The boundary conditions for the mid-Holocene experiment included changes in Earth's orbital parameters (Berger 1978) and atmospheric concentrations of greenhouse gases. In PMIP2/3, the atmospheric carbon dioxide concentration was held constant at $280 \mathrm{ppm}$, and the atmospheric methane concentration was set to 760 $\mathrm{ppb}$ for the preindustrial period but $650 \mathrm{ppb}$ during the mid-Holocene. SSTs were computed by oceanic general circulation models, and the vegetation was simulated with equilibrium or dynamic vegetation models in atmosphere-ocean-vegetation models but was fixed at the present state in atmosphere-ocean models. In addition, historical simulations of all available 13 PMIP3 models are used to assess the model performance for the tropical PWC under present climate. Basic information about the 29 models has been listed in Table 1. More details about the models and experiments are provided by Braconnot et al. (2007) and Taylor et al. (2012) and available online at http://pmip3.lsce.ipsl.fr/. To detect the tropical PWC and its changes at fine horizontal resolution, all model data were aggregated to a grid resolution of $1^{\circ}$ latitude by $1^{\circ}$ longitude using bilinear interpolation.

\section{b. Definition of PWC indices}

To directly describe the zonal-vertical structure of the tropical PWC, we use the zonal mass streamfunction to measure the zonal circulation along the equator as defined in previous studies ( $\mathrm{Yu}$ and Boer 2002; Yu and Zwiers 2010; Yu et al. 2012; Bayr et al. 2014; Schwendike et al. 2014; Ma and Zhou 2016):

$$
\Psi=2 \pi a \int_{0}^{p} u_{D} \frac{d p}{g},
$$

where $u_{D}$ denotes the divergent component of the zonal wind, which is obtained by solving the Poisson equation 
globally for the potential function with divergence as the forcing term and then calculating the divergent wind (Yu et al. 2012; Ma and Zhou 2016); $p$ is the pressure, $g$ is the gravity acceleration, and $a$ is the radius of Earth. The zonal mass flux streamfunction $\Psi$ is calculated by vertically integrating the divergent zonal wind averaged between $5^{\circ} \mathrm{S}$ and $5^{\circ} \mathrm{N}$ from the top of the atmosphere to surface. Here the levels above $100 \mathrm{hPa}$ are also included in the calculations, although only the levels below $100 \mathrm{hPa}$ are shown in the figures. We define the PWC intensity by the vertically integrated $\Psi$ of all levels averaged over the equatorial Pacific $\left(140^{\circ} \mathrm{E}-100^{\circ} \mathrm{W}\right)$. To describe the westward or eastward shift of the PWC cell, we calculate the longitude of the PWC cell center, and we also define the PWC western edge by the zero line of the vertically integrated $\Psi$ on the west of $180^{\circ}$. Similar results can be obtained with reasonable variation of the latitudinal interval chosen to quantitatively compute the PWC intensity and western edge.

In addition, we use two other kinds of PWC indices to indirectly measure the atmospheric zonal circulation. One is the tropical Indo-Pacific sea level pressure difference (dSLP) defined by Vecchi et al. (2006) as the difference in SLP averaged over the central/east Pacific $\left(5^{\circ} \mathrm{S}-5^{\circ} \mathrm{N}, 160^{\circ}-80^{\circ} \mathrm{W}\right)$ and Indian Ocean/west Pacific $\left(5^{\circ} \mathrm{S}-5^{\circ} \mathrm{N}, 80^{\circ}-160^{\circ} \mathrm{E}\right)$, which provides a useful estimate for the mean intensity of Pacific zonal surface winds (Vecchi et al. 2006; Zhang and Song 2006; Vecchi and Soden 2007; DiNezio et al. 2011, 2013). Another index is the zonal wind at $850 \mathrm{hPa}\left(U_{850}\right)$ averaged over the equatorial Pacific $\left(5^{\circ} \mathrm{S}-5^{\circ} \mathrm{N}, 140^{\circ} \mathrm{E}-100^{\circ} \mathrm{W}\right)$ to measure the surface part of PWC. A similar index defined by surface zonal wind has been used in previous studies (Luo et al. 2012; McGregor et al. 2014).

\section{c. Evaluation of climate models for the present-day tropical PWC}

Since the ability of climate models in reproducing the present-day tropical PWC determines the confidence of their results for the past climate, historical simulations undertaken by the 13 PMIP3 models (excluding CSIROMk3L-1.2 with data not available) are first evaluated against two sets of reanalysis data for the period 19792005. Note that the PMIP3 experiments have been integrated in the phase 5 of Coupled Model Intercomparison Project (CMIP5) exercise (Taylor et al. 2012), and thus those for the mid-Holocene and historical simulations are the exact same model configurations. Figure S1 in the online supplemental material illustrates the annualmean zonal mass streamfunction along the equatorial Pacific $\left(5^{\circ} \mathrm{S}-5^{\circ} \mathrm{N}\right)$ from two reanalysis datasets and the ensemble mean of historical experiments, overlaid by corresponding zonal divergent winds and vertical winds.
Positive values represent clockwise zonal circulation and negative values denote anticlockwise circulation. The PWC represented as an enclosed cell east of the Maritime Continent shows ascending motion over the western Pacific and Maritime Continent and subsidence over the eastern Pacific, with surface easterlies along the equator and westerlies in the upper troposphere. The center of the PWC cell locates in the midtroposphere $(400-500 \mathrm{hPa})$ and equatorial central Pacific $\left(\sim 150^{\circ} \mathrm{W}\right)$, while the zero line of the west side of the PWC cell locates around $155^{\circ} \mathrm{E}$. The large-scale characteristics from the historical simulations are similar to those of the PWC climatology from reanalysis datasets, demonstrating a reasonable performance of the ensemble mean of the PMIP3 models. Figure S2 further displays the reanalysis-based and simulated monthlymean vertically integrated zonal mass streamfunction along the equatorial Pacific. The maximum of the vertically integrated zonal mass streamfunction is generally stronger in June-September and December-February than in other months. The zero line over the western Pacific exhibits an obvious seasonal migration, shifting from approximately $160^{\circ} \mathrm{E}$ in March westward to around $150^{\circ} \mathrm{E}$ in June and then moving eastward. The seasonal variation pattern from historical simulations resembles that of reanalysis datasets. As such, the ensemble mean of the 13 PMIP3 models reliably captures the fundamental features of the present-day tropical PWC both on annual and seasonal scales, and it is therefore reasonable to perform the subsequent analysis.

\section{Tropical PWC changes during the mid-Holocene}

\section{a. Annual mean change}

The annual mean of zonal mass streamfunction along the equatorial Pacific $\left(5^{\circ} \mathrm{S}-5^{\circ} \mathrm{N}\right)$ during the preindustrial and mid-Holocene and their difference derived from the ensemble mean of 29 PMIP2/3 models are shown in Fig. 1, overlaid by corresponding zonal divergent winds and vertical winds from the ensemble mean of 22 models with data available (Table 1). Similar to the present-day tropical PWC climatology, the center of the preindustrial PWC cell is located in the midtroposphere $(500 \mathrm{hPa})$ and equatorial central Pacific $\left(152^{\circ} \mathrm{W}\right)$, while the zero line of the west side of the PWC cell is located around $140^{\circ} \mathrm{E}$ (Fig. 1a). The annual mean pattern of zonal mass streamfunction during the mid-Holocene resembled that during the preindustrial period, with their difference depicted by robust positive anomalies on the west side of the PWC cell (west of $\sim 155^{\circ} \mathrm{W}$ ) and negative anomalies on the east side of it across the whole troposphere (Fig. 1c), indicating a strengthening and westward 
(a) 29-PMIP-model mean: PI

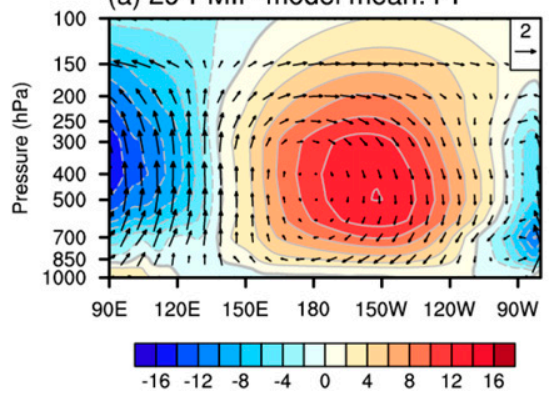

(b) 29-PMIP-model mean: MH



(c) 29-PMIP-model mean: MH-PI

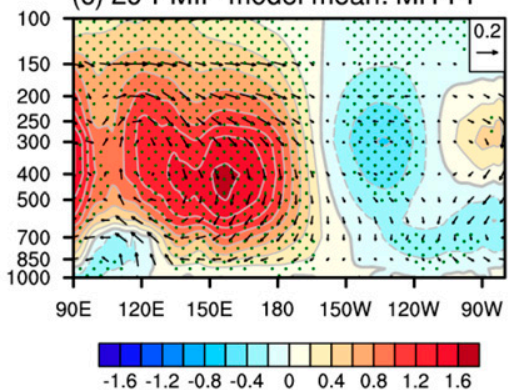

FIG. 1. Annual mean of zonal mass streamfunction (shading and contours; units: $10^{10} \mathrm{~kg} \mathrm{~s}^{-1}$ ) along the equatorial Pacific $\left(5^{\circ} \mathrm{S}-5^{\circ} \mathrm{N}\right)$ during the (a) preindustrial (PI), (b) mid-Holocene (MH), and (c) their difference (MH - PI) from the ensemble mean of 29 PMIP2/3 models. Vectors are the composite of pressure velocity $\left(\omega \times-50\right.$; units: $\left.\mathrm{Pa} \mathrm{s}^{-1}\right)$ and zonal divergent wind (units: $\left.\mathrm{m} \mathrm{s}^{-1}\right)$ from the ensemble mean of 22 PMIP $2 / 3$ models with data available. The dotted areas in (c) represent regions where at least $70 \%$ of the models agree on the sign of the change in zonal mass streamfunction.

shift of the tropical PWC cell. Quantitatively, vertically integrating all levels averaged over the equatorial $\mathrm{Pa}$ cific $\left(140^{\circ} \mathrm{E}-100^{\circ} \mathrm{W}\right)$, the mid-Holocene PWC intensity strengthened by $0.09-0.74 \times 10^{14} \mathrm{~kg}^{2} \mathrm{~m}^{-2} \mathrm{~s}^{-1}(2 \%-$ $16 \%)$ in 25 models but weakened by $0.01-0.28 \times 10^{14}$ $\mathrm{kg}^{2} \mathrm{~m}^{-2} \mathrm{~s}^{-1}(0.2 \%-6 \%)$ in the remaining four models, with an average intensification of $0.26 \times 10^{14} \mathrm{~kg}^{2} \mathrm{~m}^{-2} \mathrm{~s}^{-1}$ or $5 \%$ for all models relative to the preindustrial period (Fig. 2a; see also Table S1). On the other hand, the PWC western edge overall shifted westward by $1^{\circ}-14^{\circ}$ in 24 models but shifted eastward by $1^{\circ}-4^{\circ}$ in four models, with generally no shift in the remaining one model and an average westward shift of $4^{\circ}$ for all models during the mid-Holocene (Fig. 2b; Table S1). Besides the western edge, the PWC cell center also showed an extent of shift, with a westward shift of $1^{\circ}-19^{\circ}$ in 16 models, a eastward shift of $3^{\circ}-22^{\circ}$ in 4 models, and no shift in the other 9 models, yielding an average westward shift by $3^{\circ}$ for all models (Fig. 2c; Table S1), showing an extent of uncertainty among models. The strengthening of the intensity and westward shift of the western edge of the PWC cell in the ensemble mean of 15 PMIP2 models were overall similar in magnitude to those from the 14PMIP3-model mean, but the westward shift of the PWC cell center was much stronger in the former than in the latter (Figs. 2a-c; see also Table S1).

Consistent with annual changes in above direct PWC indices, the annual equatorial Pacific east-west SLP difference increased by $0.01-0.40 \mathrm{hPa}(0.4 \%-802 \%)$ in 25 models but reduced by $0.01-0.24 \mathrm{hPa}(1 \%-13 \%)$ in the remaining four models, with an average increase of $0.14 \mathrm{hPa}$ or $8 \%$ for all models during the mid-Holocene (Fig. 2d; Table S1). Correspondingly, annual easterly wind at $850 \mathrm{hPa}$ over the equatorial Pacific $\left(5^{\circ} \mathrm{S}-5^{\circ} \mathrm{N}\right.$, $\left.140^{\circ} \mathrm{E}-100^{\circ} \mathrm{W}\right)$ strengthened by $0.02-0.70 \mathrm{~m} \mathrm{~s}^{-1}(0.3 \%-$ $11 \%)$ in 27 models but weakened by $0.62 \mathrm{~m} \mathrm{~s}^{-1}(9 \%)$ in FGOALS-1.0g and by $0.17 \mathrm{~m} \mathrm{~s}^{-1}(4 \%)$ in GISS-E2-R, contributing to an average enhancement of low-level trade winds by $0.29 \mathrm{~m} \mathrm{~s}^{-1}$ or $4 \%$ for all models (Fig. 2e; Table S1). The correlation coefficient between the midHolocene changes in dSLP and $U_{850}$ is -0.76 , which is significant at the $99 \%$ confidence level (Table 2) and indicates a close dynamical connection between largescale zonal difference of SLP and zonal wind stress (Clarke and Lebedev 1996).

To depict the relationship among the PWC indices straightforwardly, Fig. 3 shows the scatterplot of the annual changes in PWC intensity versus shifts of the western edge and center of the PWC cell and changes in dSLP and zonal wind at $850 \mathrm{hPa}$ between the midHolocene and preindustrial periods. Most models show a strengthening of the PWC intensity, westward shifts of both the western edge and center of the PWC cell, increased dSLP, and enhancement of low-level trade winds. There were some relations between the PWC intensity change and shift of both the PWC western edge and PWC cell center, with the correlation coefficients of -0.37 and -0.32 being significant at the 95\% and $90 \%$ confidence level, respectively (Figs. 3a and $3 b$; Table 2), but explaining only a small part of variance, suggesting that other processes were rather more important for the PWC intensity change. Besides, the changes in PWC intensity were positively correlated with changes in dSLP but negatively correlated with those in $U_{850}$, with the correlation coefficients of 0.59 and -0.71 being significant at the $99 \%$ confidence level (Figs. 3c and 3d; Table 2). The shifts of the PWC western edge also significantly correlated with changes in dSLP and $U_{850}$ both at the $99 \%$ confidence level, whereas the correlations between the shifts of PWC cell center and the above three indices are insignificant at the $99 \%$ confidence level (Table 2).

The zonal distributions of the annual climatology of vertically integrated zonal mass streamfunction and 

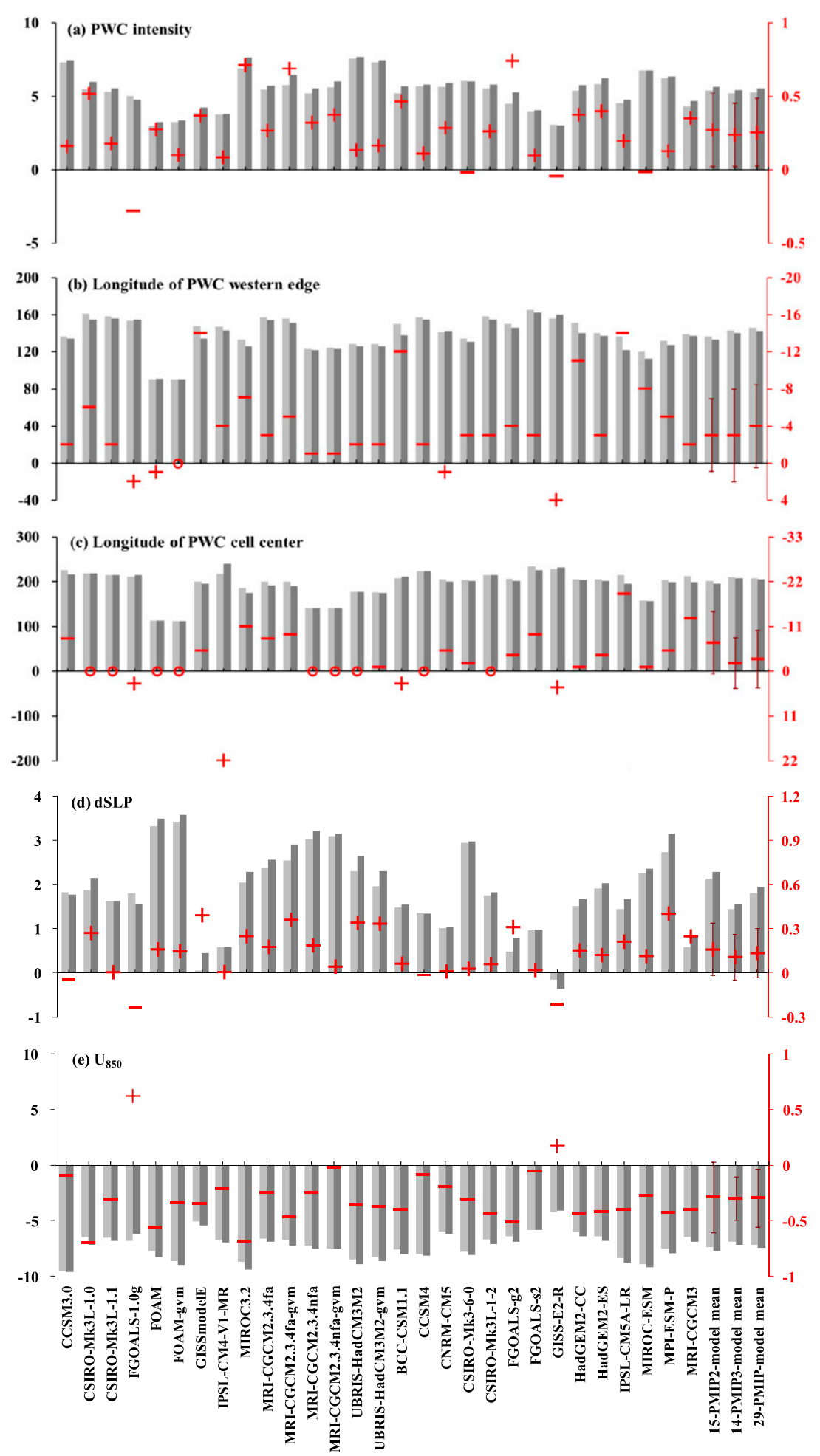

FIG. 2. Annual mean of the (a) PWC intensity (units: $10^{14} \mathrm{~kg}^{2} \mathrm{~m}^{-2} \mathrm{~s}^{-1}$ ), (b) longitude of PWC western edge (units: ${ }^{\circ}$ ), (c) longitude of PWC cell center (units: ${ }^{\circ}$ ), (d) dSLP (units: $\mathrm{hPa}$ ), and (e) zonal wind at $850 \mathrm{hPa}$ (units: $\mathrm{m} \mathrm{s}^{-1}$ ) during the preindustrial (light gray bars; left $y$ axis), mid-Holocene (dark gray bars; left $y$ axis), and their difference (red signs; right $y$ axis) from the 15 PMIP2 and 14 PMIP3 models and their ensemble means. Red plus (minus) signs represent positive (negative) change, and open circles represent no change between the mid-Holocene and preindustrial periods. The red error bar for the model ensemble mean change represents the range of the difference in the models of concern. 
TABLE 2. Correlation coefficient between the mid-Holocene minus preindustrial changes in PWC intensity over the equatorial Pacific $\left(5^{\circ} \mathrm{S}-5^{\circ} \mathrm{N}, 140^{\circ} \mathrm{E}-100^{\circ} \mathrm{W}\right)$ vertically integrated from top level to $1000 \mathrm{hPa}$, shift of PWC western edge, shift of PWC cell center, changes in dSLP between the central/east Pacific $\left(5^{\circ} \mathrm{S}-5^{\circ} \mathrm{N}, 160^{\circ}-80^{\circ} \mathrm{W}\right)$ and Indian Ocean/west Pacific $\left(5^{\circ} \mathrm{S}-5^{\circ} \mathrm{N}, 80^{\circ}-160^{\circ} \mathrm{E}\right)$, and changes in zonal wind at $850 \mathrm{hPa}\left(U_{850}\right)$ over $\left(5^{\circ} \mathrm{S}-5^{\circ} \mathrm{N}, 140^{\circ} \mathrm{E}-100^{\circ} \mathrm{W}\right)$ based on all $29 \mathrm{PMIP} 2 / 3$ models. Correlation coefficients that are statistically significant at the $95 \%$ and $99 \%$ confidence levels are in italic and boldface, respectively.

\begin{tabular}{|c|c|c|c|c|}
\hline & PWC western edge shift & PWC cell center shift & dSLP & $U_{850}$ \\
\hline PWC intensity & -0.37 & -0.32 & 0.59 & -0.71 \\
\hline PWC western edge shift & - & 0.27 & -0.47 & 0.47 \\
\hline PWC cell center shift & - & - & -0.38 & 0.26 \\
\hline dSLP & - & - & - & -0.76 \\
\hline
\end{tabular}

zonal wind at $850 \mathrm{hPa}$ along the equatorial Pacific $\left(5^{\circ} \mathrm{S}-\right.$ $5^{\circ} \mathrm{N}$ ) were similar between the preindustrial and midHolocene periods in the multimodel ensemble mean (Fig. 4). Both of the mean states showed a maximum of vertically integrated zonal mass streamfunction and lowlevel trade winds in central Pacific around $150^{\circ} \mathrm{W}$ and the strongest ascending motion in the Maritime Continent around $120^{\circ} \mathrm{E}$ (figure not shown). During the mid-Holocene, the vertically integrated zonal mass streamfunction increased over the western Pacific and both the maximum center (from $152^{\circ}$ to $157^{\circ} \mathrm{W}$ ) and the western edge (from $140^{\circ}$ to $137^{\circ} \mathrm{E}$ ) slightly shifted westward, the average ascending motion strengthened over the Maritime Continent, and the easterlies at $850 \mathrm{hPa}$ enhanced over the central and western Pacific, collectively showing a clear picture of the strengthening and westward shift of the tropical PWC relative to the preindustrial period.

\section{b. Seasonal variation}

Considering the seasonality of the energy exchange between the atmosphere and ocean, there is a large seasonal variation in the tropical PWC (Yu et al. 2012; Schwendike et al. 2014). For the preindustrial climatology, the maximum of the vertically integrated zonal mass streamfunction along the equatorial Pacific $\left(5^{\circ} \mathrm{S}-\right.$ $5^{\circ} \mathrm{N}$ ) was strongest in June-September but weakest in March-May, with the zero line over the western Pacific exhibiting an obvious seasonal migration and shifting from approximately $140^{\circ} \mathrm{E}$ in March westward to $\sim 130^{\circ} \mathrm{E}$ in June and then moving eastward, as derived from the ensemble mean of the 29 PMIP2/3 models (Fig. 5a). There was also a large seasonal difference of the PWC change between the mid-Holocene and preindustrial periods. The vertically integrated zonal mass streamfunction showed robust positive anomalies from June through October but negative anomalies from February to May over the western and central Pacific $\left(120^{\circ} \mathrm{E}-160^{\circ} \mathrm{W}\right)$, whereas the opposites held true over the eastern Pacific (Fig. 5c), indicating an enhancement of the tropical PWC in the mid-Holocene boreal warm seasons [June-October (JJASO)] but a reduction in boreal cold seasons [December-April (DJFMA)], which was consistent with previous single-model study (Kitoh and Murakami 2002). With respect to the preindustrial period, both the zero line and maximum center of the vertically integrated zonal mass streamfunction shifted westward from July through October during the mid-Holocene (Figs. 5a and 5b). Altogether, the boreal warm-season difference partially offset the cold-season difference, resulting in the strengthening and westward shift of the annual mean PWC during the mid-Holocene.

\section{c. Dynamic mechanism for the mid-Holocene tropical PWC change}

As mentioned above, the mid-Holocene change of the annual mean PWC is mainly attributed to the change in boreal warm seasons. In response to the mid-Holocene orbital forcing primarily by precession, the Northern Hemisphere received more insolation at the top of the atmosphere in boreal warm seasons (left panel of Fig. 6; Berger 1978; Kitoh and Murakami 2002), leading to large-scale increase in land surface temperatures at the middle and high latitudes but decrease at some locations in the low latitudes (Fig. 7c). As a result, the meridional temperature gradient decreased through the low to middle and high latitudes, which was favorable to anomalous southerly winds that brought excess water vapor from the tropics in the lower troposphere. Moreover, the mid-Holocene SSTs were slightly warmer over the North Pacific and Atlantic but colder over most of the tropical Pacific (Fig. 7c). Because of stronger surface warming over Asia than over the North Pacific, the large-scale zonal land-sea thermal contrast and hence SLP gradient increased accordingly, which were beneficial to winds and moisture transport from the ocean to the continent in the lower troposphere. As confirmed in Fig. 8c, the anomalous water vapor flux converged in the Asian and North African monsoon 

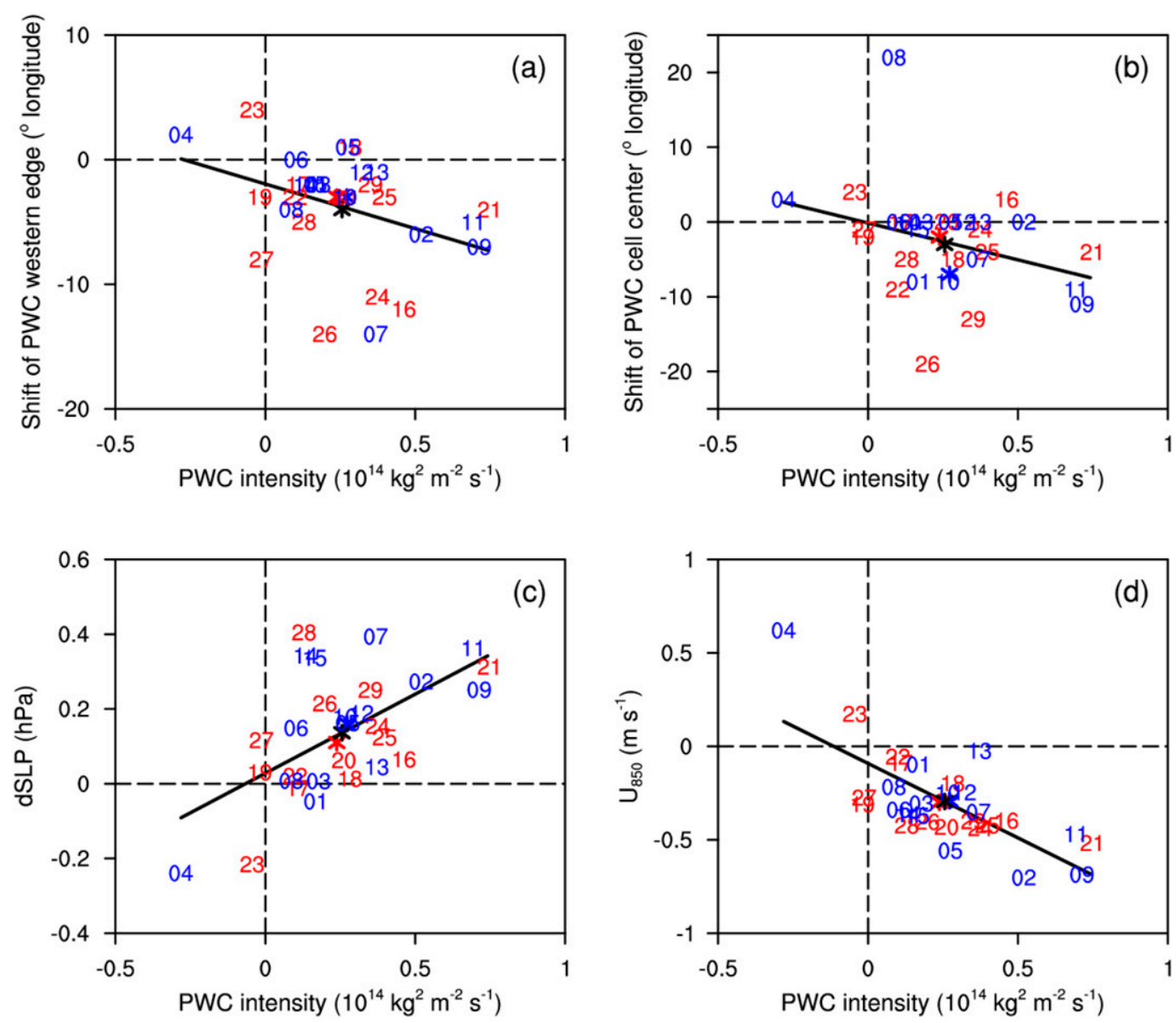

FIG. 3. Mid-Holocene minus preindustrial changes in PWC intensity (units: $10^{14} \mathrm{~kg}^{2} \mathrm{~m}^{-2} \mathrm{~s}^{-1}$ ) vs shifts of (a) PWC western edge and (b) PWC cell center (units: ${ }^{\circ}$ longitude) and changes in (c) dSLP (units: hPa) and (d) zonal wind at $850 \mathrm{hPa}$ (units: $\mathrm{m} \mathrm{s}^{-1}$ ). Each number represents a model ID (see Table 1), with blue denoting a PMIP2 model and red a PMIP3 model; blue, red, and black stars represent the ensemble mean of 15 PMIP2 models, 14 PMIP3 models, and all models, respectively; and the black solid line denotes the least squares linear fit of the changes based on all models.

regions, leading to increased monsoon rainfall over these key tropical regions (enclosed by the red ellipse in Figs. $8 \mathrm{c}$ and $9 \mathrm{c}$ ) during the mid-Holocene boreal warm seasons, which was consistent with previous studies (e.g., Anderson et al. 1988; Kutzbach and Liu 1997; Joussaume et al. 1999; Wang 1999; Braconnot et al. 2000; Bosmans et al. 2012; Jiang et al. 2013, 2015; Zheng et al. 2013). The enhanced convective heating associated with the strengthened Asian and North African monsoons intensified a large-scale thermally direct east-west circulation as shown in Krishnamurti (1971) and Chang and $\mathrm{Li}$ (2000), which was exhibited as vigorous anomalous easterlies extending from approximately $75^{\circ} \mathrm{W}$ of the tropical southeastern Pacific across the central and western Pacific farther westward to approximately $50^{\circ} \mathrm{E}$ of the equatorial Indian Ocean (Fig. 10c). Moreover, the strengthened Indian monsoon (Fig. 9c) could also induce a Kelvin wave response to the east. The easterly anomalies associated with the Kelvin wave response thus strengthened the North Pacific subtropical high (Wu et al. 2009), which extended farther westward with anomalous anticyclone circulation over the North $\mathrm{Pa}$ cific and anomalous easterlies over the equatorial western Pacific (Fig. 10c). Additionally, the anomalous easterlies in the equatorial Indian Ocean led to a dipole rainfall-SST change pattern through the Bjerknes feedback, showing decreased precipitation and colder SSTs in the southeastern Indian Ocean off Java and Sumatra but increased precipitation and slightly warmer SSTs in the western Indian Ocean (Figs. 7c and 9c). As a whole, because the surface part of PWC is characterized by low-level easterlies over the equatorial Pacific (Fig. 1), the anomalous easterlies over the equatorial western and central Pacific and Indian Ocean thus 
(a) Vertically integrated zonal mass streamfunction



(b) $850 \mathrm{hPa}$ zonal wind

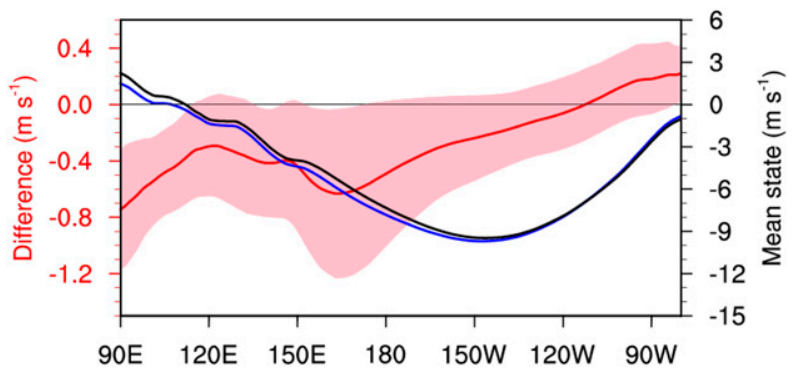

FIG. 4. Annual mean of (a) vertically integrated zonal mass streamfunction (units: $10^{14} \mathrm{~kg}^{2} \mathrm{~m}^{-2} \mathrm{~s}^{-1}$ ) and (b) zonal wind at $850 \mathrm{hPa}$ (units: $\left.\mathrm{m} \mathrm{s}^{-1}\right)$ along the equatorial Pacific $\left(5^{\circ} \mathrm{S}-5^{\circ} \mathrm{N}\right)$ during the preindustrial (black line; right $y$ axis), mid-Holocene (blue line; right $y$ axis), and their difference (red line; left $y$ axis) from the ensemble mean of 29 PMIP2/3 models. Light pink shading represents the range of the difference between the two periods in all models.

indicated a strengthening and westward shift of the tropical PWC during the mid-Holocene boreal warm seasons (Fig. 5c). Note that at the large scale, most of the PMIP2/3 models share similar response with their ensemble mean as shown from the model agreement value dotted in Figs. 7 and 9 and from a whole picture of individual PMIP2/3 models in Figs. S3 and S4. Previous studies showed that a stronger Walker circulation correlates positively with the orographic rainfall enhancement over the Maritime Continent due to mechanically forced upslope flow (Roe 2005; Sobel et al. 2011), but negatively with the rainfall over the western Pacific warm pool (e.g., Dayem et al. 2007). Consistent with these ideas and the strengthened mid-Holocene boreal warm-season PWC, the anomalous water vapor flux convergence explained the intensification of precipitation and ascending motion over the Maritime Continent, while the anomalous water vapor flux divergence suppressed the tropical western and southern Pacific precipitation (Figs. 8c and 9c). Note that the ascending motion also intensified over the northern Indian Ocean, which was mainly due to the westward shift of the tropical PWC, leading to the convergence of water vapor flux and thus the enhanced precipitation in the northern Indian Ocean (Figs. 8c and 9c).

In boreal cold seasons, the Northern Hemisphere received less insolation at the top of the atmosphere during the mid-Holocene (left panel of Fig. 6), and surface temperatures decreased at the low and middle latitudes over land and most of the oceans (Fig. 7b). Surface cooling was stronger in the East Asian continent than over the surrounding oceans at the tropics and middle latitudes, resulting in decreases in both meridional and zonal land-sea thermal contrast, and hence the SLP gradient, which was unfavorable to winds and water vapor transport from the ocean toward the land in the lower troposphere (Fig. 10b). As further seen from Figs. $8 \mathrm{~b}$ and $9 \mathrm{~b}$, the anomalous water vapor flux generally diverged and thus rainfall decreased in the land monsoon areas of Asia and North Africa. As a result, the weakened convective heating associated with the weakened Asian and North African monsoons suppressed the large-scale east-west circulation (Krishnamurti (a) 29-PMIP-model mean: PI
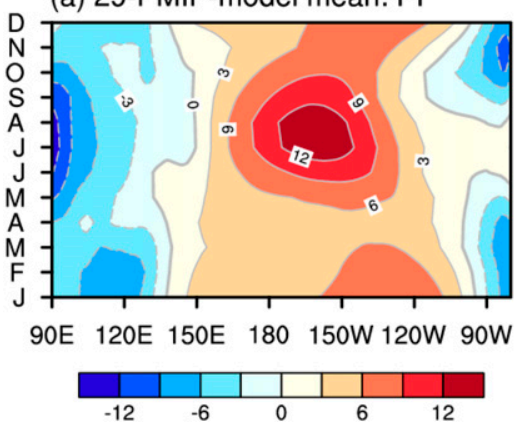

(b) 29-PMIP-model mean: $\mathrm{MH}$
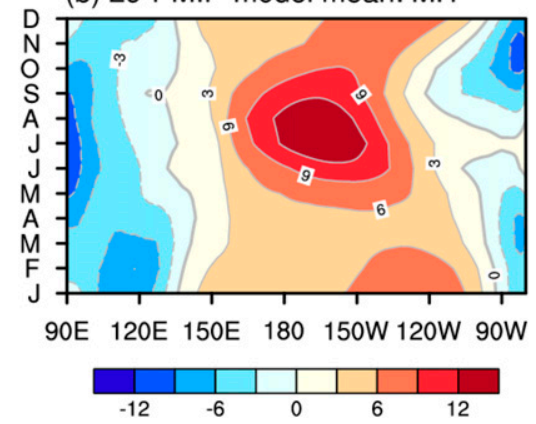

(c) 29-PMIP-model mean: MH-PI

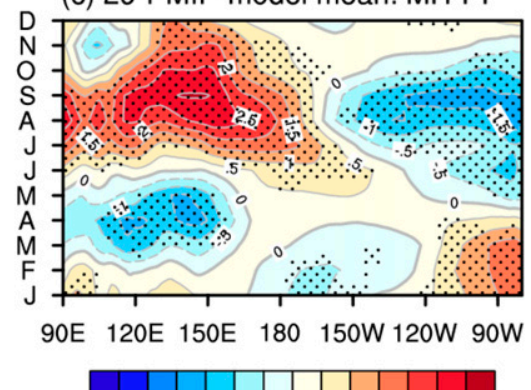

$\begin{array}{lllllllllll} & -3 & -2 & -1 & 0 & 1 & 2 & 3\end{array}$

FIG. 5. Monthly mean of vertically integrated zonal mass streamfunction (units: $\left.10^{14} \mathrm{~kg}^{2} \mathrm{~m}^{-2} \mathrm{~s}^{-1}\right)$ along the equatorial Pacific $\left(5^{\circ} \mathrm{S}-5^{\circ} \mathrm{N}\right.$ ) during the (a) preindustrial (PI), (b) mid-Holocene (MH), and (c) their difference (MH - PI) from the ensemble mean of 29 PMIP2/3 models. The dotted areas in (c) represent regions where at least $70 \%$ of the models agree on the sign of the change. Note that this figure shows the maximum value of vertically integrated zonal mass streamfunction for each longitude and month. 


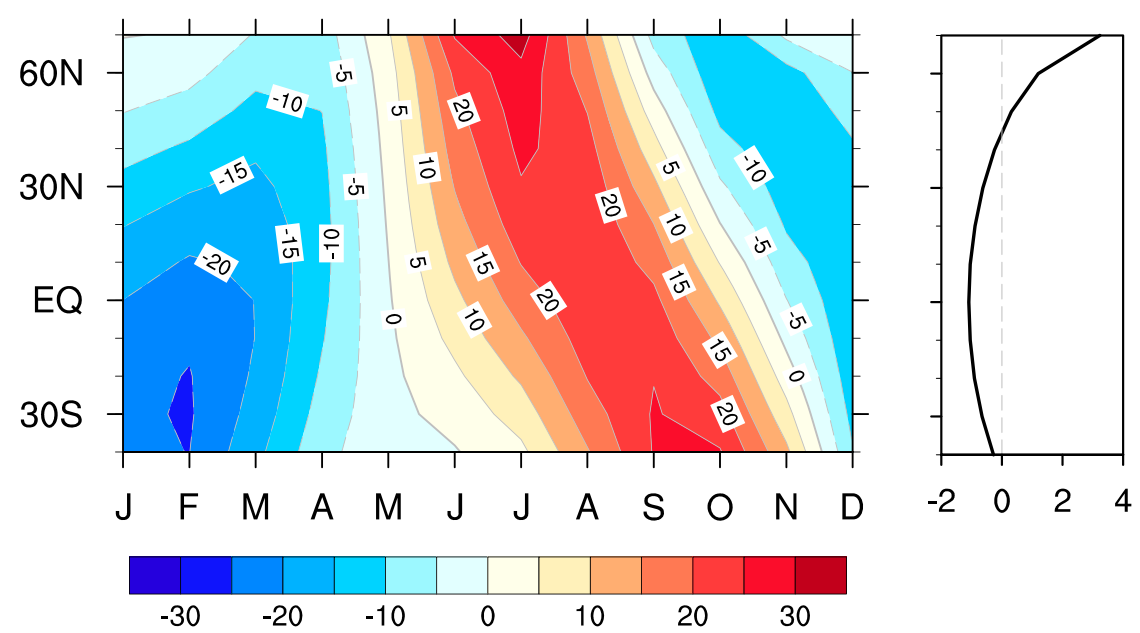

FIG. 6. Latitude-month distribution of the mid-Holocene minus preindustrial changes in incoming solar radiation at the top of the atmosphere according to Berger (1978), with annual mean changes being shown on the right panel (units: $\mathrm{W} \mathrm{m}^{-2}$ ).

et al. 1973; Chang and Li 2000), leading to anomalous westerlies extending from approximately $50^{\circ} \mathrm{E}$ of the equatorial Indian Ocean across the western and central Pacific farther eastward to approximately $80^{\circ} \mathrm{W}$ of the tropical southeastern Pacific (Fig. 10b) and thus indicating a weakening of the tropical PWC during the mid-Holocene boreal cold seasons (Fig. 5c). Accordingly, the anomalous water vapor flux divergence suppressed the precipitation and rising motion over the Maritime Continent and Australia, while the anomalous water vapor flux convergence

\section{(a) 29-PMIP-model mean: Annual}

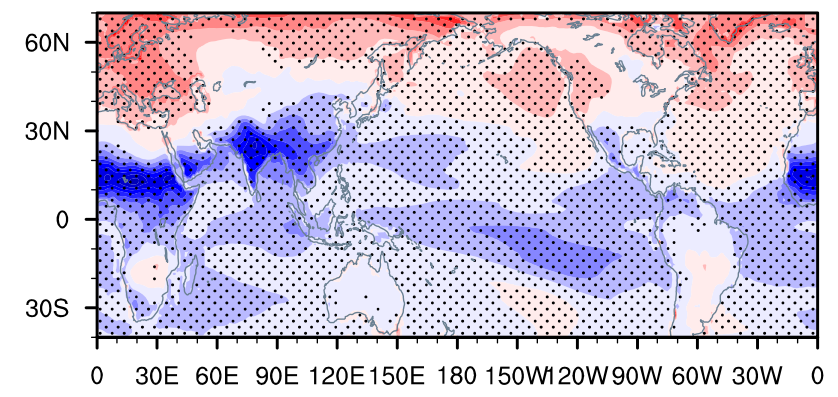

(b) 29-PMIP-model mean: DJFMA

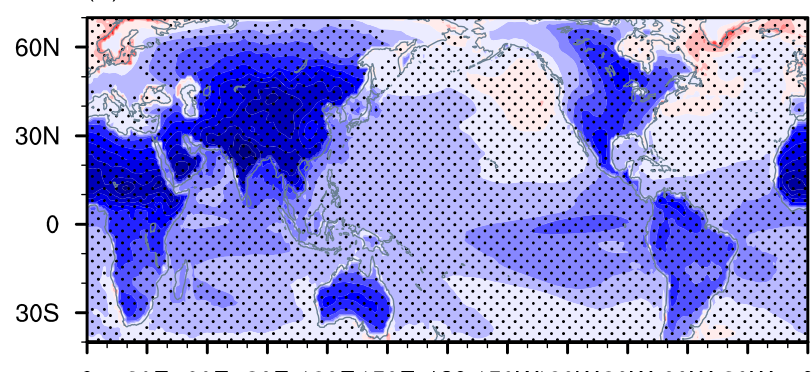

(c) 29-PMIP-model mean: JJASO

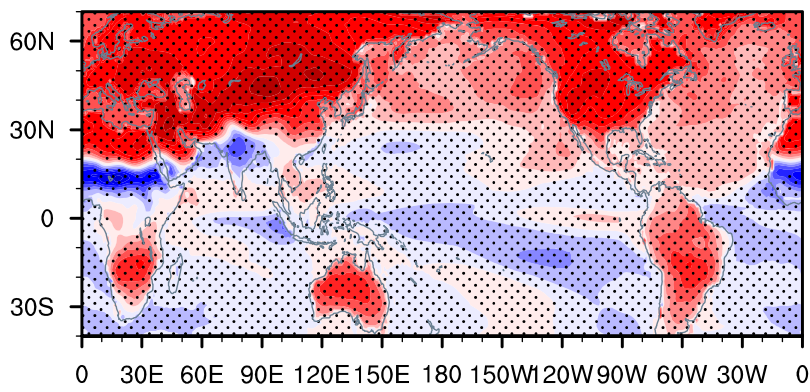

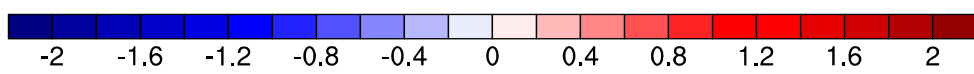

FIG. 7. Mid-Holocene minus preindustrial changes in (a) annual, (b) DJFMA, and (c) JJASO land surface 2-m air temperatures from the ensemble mean of 29 PMIP2/3 models and sea surface temperatures from the ensemble mean of 26 PMIP2/3 models with data available (units: ${ }^{\circ} \mathrm{C}$ ). The dotted areas represent regions where at least $70 \%$ of the models agree on the sign of the change. 
(a) 13-PMIP3-model mean: Annual

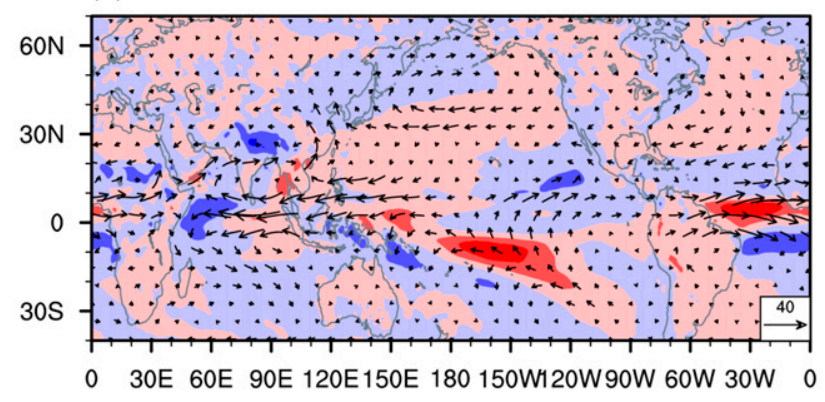

(b) 13-PMIP3-model mean: DJFMA

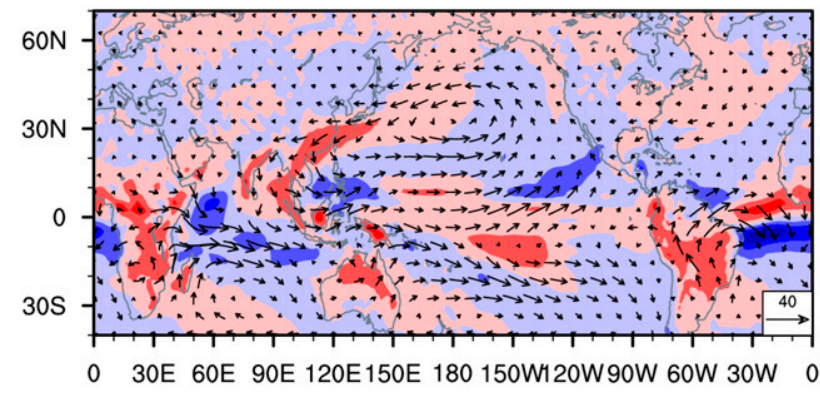

(c) 13-PMIP3-model mean: JJASO

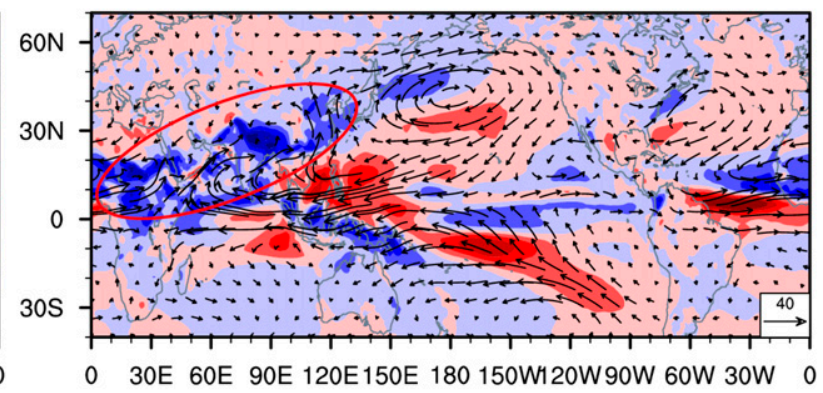

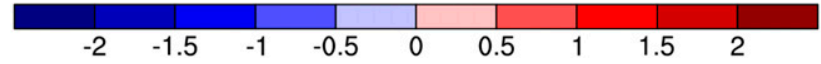

FIG. 8. Mid-Holocene minus preindustrial changes in (a) annual, (b) DJFMA, and (c) JJASO vertically integrated water vapor flux (arrows; units: $\mathrm{kg} \mathrm{m}^{-1} \mathrm{~s}^{-1}$ ) and its divergence (shading; units: $\mathrm{mm} \mathrm{day}^{-1}$ ) obtained from 13 PMIP3 models (excluding CSIRO-Mk3L-1.2) with specific humidity and wind data available. The vertical integration of water vapor flux is performed from the surface to $300 \mathrm{hPa}$, and the impacts of topography have been removed using the surface pressure. The units of divergence has been converted to mm day ${ }^{-1}$, assuming the density of liquid water as $1 \mathrm{~g} \mathrm{~cm}^{-3}$. The regions enclosed by the red ellipse in (c) represent the key monsoon regions over Asia and North Africa.

led to increased precipitation over the equatorial Indian Ocean and the tropical western Pacific (Figs. 8b and 9b). Taken together, in response to the annual mean orbital forcing (right panel of Fig. 6), the changes in boreal warm seasons partially offset the boreal cold-season changes, leading to an annual net effect similar to the boreal warmseason one with anomalous easterlies in the equatorial western and central Pacific and Indian Ocean on the annual scale (Fig. 10a). This resulted in the enhancement and westward shift of the annual mean PWC during the midHolocene.

The mean states of the mid-Holocene tropical Pacific SSTs and salinity have been reconstructed from a variety of paleoclimate records, which could indirectly reflect some features of the tropical PWC change. The PMIP2/3 model results showed that the mid-Holocene annual SSTs were generally colder over the tropical Pacific with little change in the equatorial Pacific SST gradient (Fig. 7a). However, reconstructions from magnesium/ calcium ratios in planktonic foraminifera showed relative cooling of the mid-Holocene SST in the eastern equatorial Pacific with respect to the western Pacific, suggestive of enhanced zonal SST gradients, strengthened trade winds, and thus more vigorous Walker circulation (Koutavas et al. 2002). This conclusion was consistent with the simulated enhancement of the tropical annual PWC during the mid-Holocene in the present study, although the strengthened trade winds were mainly derived from the intensified large-scale east-west circulation due to stronger Asian and North African monsoons in the boreal warm seasons. On the other hand, some authors have inferred relative warming or little change of the mid-Holocene SST from the present day in the eastern equatorial Pacific on the basis of geoarcheologic evidence (Sandweiss et al. 1996; Andrus et al. 2002; Lea et al. 2006; Timmermann et al. 2014), and in the western equatorial Pacific based on alkenone data (Timmermann et al. 2014), disagreeing with the annual cooling (Fig. 7a) but somehow agreeing with the boreal warm-season situation in the simulations (Fig. 7c). Therefore, there are inconsistencies among different SST records, which may be related to different seasonal sensitivities as suggested by Timmermann et al. (2014), calling for more reconstructions using multisource proxy data with higher spatial and temporal resolutions to better perform model-data comparison. In addition, evidence reconstructed from oxygen isotope ratios in coral (Gagan 
(a) 29-PMIP-model mean: Annual

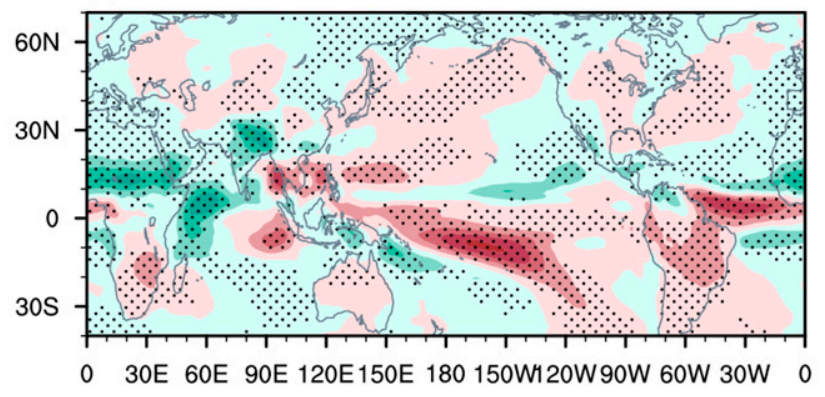

(b) 29-PMIP-model mean: DJFMA



(c) 29-PMIP-model mean: JJASO

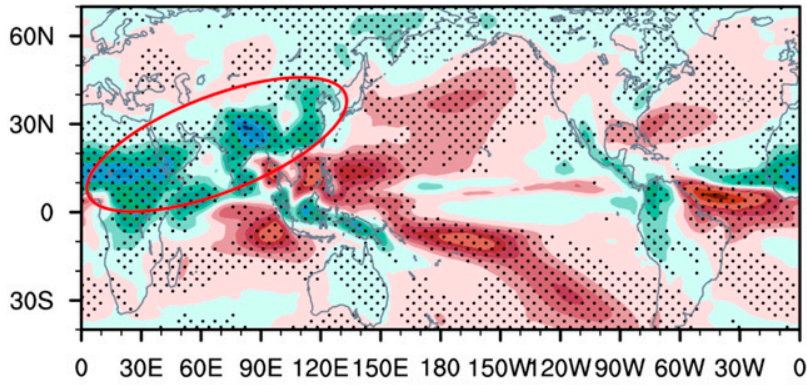

\begin{tabular}{|cc|c|c|c|c|c|c|c|c|c|c|c|c|c|}
\hline & & & & & & & & & & & & & & \\
-2 & -1.5 & -1 & -0.8 & -0.6 & -0.4 & -0.2 & 0 & 0.2 & 0.4 & 0.6 & 0.8 & 1 & 1.5 & 2
\end{tabular}

FIG. 9. Mid-Holocene minus preindustrial changes in (a) annual, (b) DJFMA, and (c) JJASO precipitation (units: $\mathrm{mm}^{\mathrm{day}}{ }^{-1}$ ) from the ensemble mean of 29 PMIP2/3 models. The dotted areas represent regions where at least $70 \%$ of the models agree on the sign of the change. The regions enclosed by the red ellipse in (c) represent the key monsoon regions over Asia and North Africa.

et al. 1998; Tudhope et al. 2001) and marine sediments (Stott et al. 2004) also suggested that the western equatorial Pacific was more saline in the mid-Holocene, which implied increased evaporation or decreased precipitation and thus agreed with the multimodel result (Fig. 9a).

Because the PWC is a thermally direct circulation over the tropical Pacific, the equatorial Pacific zonal SST gradient is thought to be an important driver of the PWC intensity (Philander 1990). Previous studies have shown that the La Niña-like pattern of the equatorial Pacific SST contributes to the strengthening of the long-term PWC, whereas the El Niño-like SST change pattern explains the PWC weakening (Koutavas et al. 2002; Meng et al. 2012; Tokinaga et al. 2012b; Liu et al. 2013; Sandeep et al. 2014; Ma and Zhou 2016). However, Ma et al. (2012) found that without any change in equatorial Pacific SST gradient, the mean advection of stratification change by climatological vertical motion acts to slow down the tropical PWC in response to global warming. In the PMIP2/3 simulations, the mid-Holocene equatorial Pacific SST showed little change in boreal warm seasons (Fig. 7c), but the tropical PWC was enhanced due to the anomalous easterlies over the equatorial western and central Pacific, which mainly resulted from the intensified planetary-scale east-west circulation stemming from the strengthening of the Asian and North African monsoons during that time. On the other hand, a La Niña-like SST change pattern occurred in the midHolocene boreal cold seasons (Fig. 7b), but the tropical PWC was weakened due to the anomalous westerlies over the equatorial western Pacific, which were primarily attributed to the weakening of the Asian and North African monsoons and associated large-scale east-west circulation. Therefore, the present study stressed the important role Asian and North African monsoons (regions enclosed by the red ellipses in Figs. 8c and 9c) play in causing the change of the large-scale east-west circulation. The change of the equatorial Pacific SST change pattern is not critical for the tropical PWC change during the mid-Holocene. In this sense, to better verify the simulated PWC change, further effort should be devoted to reconstruct the mid-Holocene surface circulation in the equatorial Pacific.

\section{Conclusions}

The annual mean change in the tropical PWC, based on the PWC indices, as well as its seasonal variation during the mid-Holocene were investigated using 29 coupled models under the protocol of the PMIP2/3 simulations. The primary conclusions are as follows. 
(a) 29-PMIP-model mean: Annual

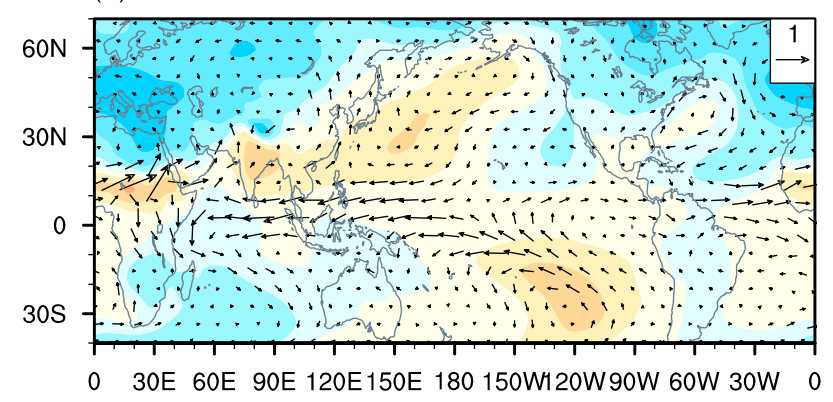

(b) 29-PMIP-model mean: DJFMA

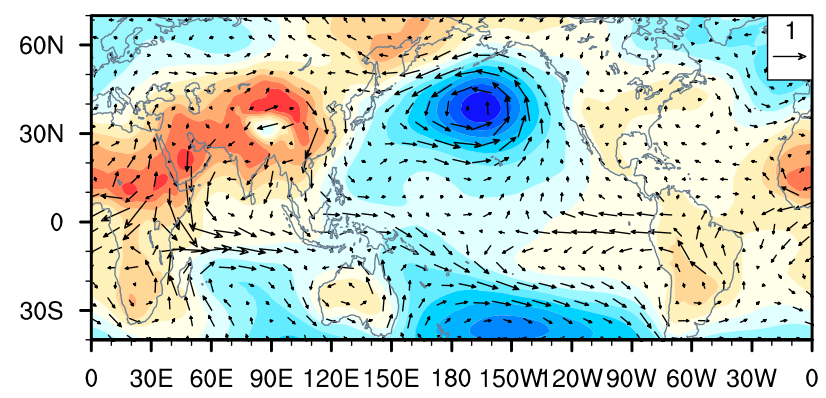

(c) 29-PMIP-model mean: JJASO

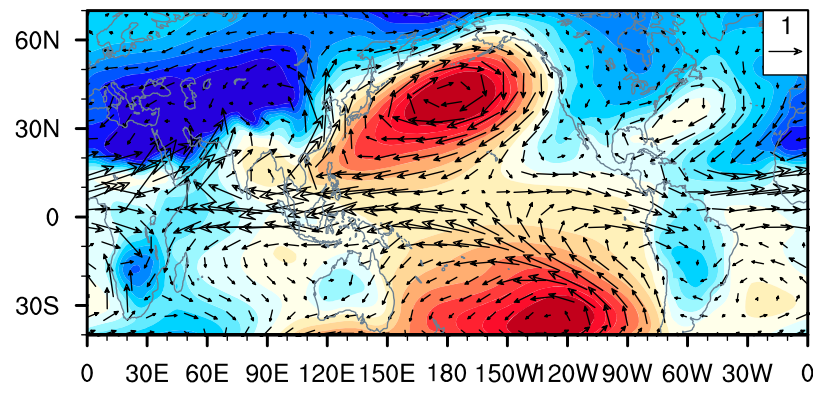



FIG. 10. Mid-Holocene minus preindustrial changes in (a) annual, (b) DJFMA, and (c) JJASO sea level pressures (shading; units: hPa) and winds at $850 \mathrm{hPa}$ (vectors; units: $\mathrm{m} \mathrm{s}^{-1}$ ) from the ensemble mean of $29 \mathrm{PMIP} 2 / 3$ models.

As measured by the zonal mass streamfunction, the tropical PWC cell is characterized by rising motion over the western Pacific and Maritime Continent, subsidence over the eastern Pacific, surface easterlies along the equator, and westerlies in the upper troposphere. With respect to the preindustrial period, the annual mean of the PWC intensity strengthened in 25 models but weakened in the remaining 4 models, with an average intensification of $0.26 \times 10^{14} \mathrm{~kg}^{2} \mathrm{~m}^{-2} \mathrm{~s}^{-1}$ or $5 \%$ for all models during the mid-Holocene. The western edge and center of the PWC cell shifted westward in most models, with an average of $4^{\circ}$ and $3^{\circ}$, respectively, for the ensemble mean of the 29 models. The mid-Holocene annual changes in the tropical PWC were accompanied by an average increase in the equatorial Indo-Pacific eastwest SLP difference by $0.14 \mathrm{hPa}$ or $8 \%$ and an enhancement of low-level trade winds over the equatorial Pacific by $0.29 \mathrm{~m} \mathrm{~s}^{-1}$ or $4 \%$ for the 29 -model ensemble mean. There was a close relationship among the annual changes in PWC intensity, the shifts of PWC western edge and PWC cell center, and the changes in equatorial Indo-Pacific east-west SLP difference and low-level trade winds over the equatorial Pacific during the midHolocene.

On the seasonal scale, the mid-Holocene tropical PWC intensified and shifted westward in boreal warm seasons (JJASO) but weakened in boreal cold seasons (DJFMA) relative to the preindustrial period. In response to the mid-Holocene orbital forcing, the asymmetric surface warming led to large-scale changes in meridional temperature gradient and zonal land-sea thermal contrast in the Northern Hemisphere and hence strengthened Asian and North African monsoon rainfall in boreal warm seasons, which intensified a planetaryscale east-west circulation, resulting in anomalous easterlies over the equatorial western Pacific and Indian Ocean in the lower troposphere and thus the enhancement of the tropical PWC. The opposite occurred in the mid-Holocene boreal cold seasons. Moreover, the enhanced Indian monsoon also strengthened the Pacific subtropical high, which extended farther westward and led to the anomalous easterlies over the equatorial western Pacific in boreal warm seasons. Because of the orbital forcing, the annual changes followed the boreal warm-season ones, contributing to the strengthening of the annual mean PWC during the mid-Holocene. Altogether, the change in the monsoon rainfall over the key tropical regions of Asia and North Africa and associated large-scale east-west circulation played a more essential role than the equatorial Pacific SST change pattern in influencing the tropical PWC strength during the mid-Holocene. 
Acknowledgments. We sincerely thank the two anonymous reviewers for their insightful comments and suggestions to improve this manuscript. We also thank the climate modeling groups (listed in Table 1) for producing and making available their model output. This research was jointly supported by the National Key R\&D Program of China (2017YFA0603404), the National Natural Science Foundation of China (41625018 and 41421004), China National 973 project 2015CB453200, and NSFC Grant 41630423.

\section{REFERENCES}

An, S.-I., and J. Choi, 2014: Mid-Holocene tropical Pacific climate state, annual cycle, and ENSO in PMIP2 and PMIP3. Climate Dyn., 43, 957-970, https://doi.org/10.1007/s00382-013-1880-z.

Anderson, P. M., and Coauthors, 1988: Climatic changes of the last 18,000 years: Observations and model simulations. Science, 241, 1043-1052, https://doi.org/10.1126/science.241.4869.1043.

Andrus, C. F. T., D. E. Crowe, D. H. Sandweiss, E. J. Reitz, and C. S. Romanek, 2002: Otolith $\delta^{18} \mathrm{O}$ record of mid-Holocene sea surface temperatures in Peru. Science, 295, 1508-1511, https://doi.org/10.1126/science.1062004.

Bayr, T., D. Dommenget, T. Martin, and S. B. Power, 2014: The eastward shift of the Walker circulation in response to global warming and its relationship to ENSO variability. Climate Dyn., 43, 2747-2763, https://doi.org/10.1007/s00382-014-2091-y.

Berger, A. L., 1978: Long-term variations of daily insolation and Quaternary climatic changes. J. Atmos. Sci., 35, 2362-2367, https:// doi.org/10.1175/1520-0469(1978)035<2362:LTVODI >2.0.CO;2.

Bjerknes, J., 1969: Atmospheric teleconnections from the equatorial Pacific. Mon. Wea. Rev., 97, 163-172, https://doi.org/ 10.1175/1520-0493(1969)097<0163:ATFTEP >2.3.CO;2.

Bosmans, J. H. C., S. S. Drijfhout, E. Tuenter, L. J. Lourens, F. J. Hilgen, and S. L. Weber, 2012: Monsoonal response to mid-Holocene orbital forcing in a high resolution GCM. Climate Past, 8, 723-740, https://doi.org/10.5194/cp-8-723-2012.

Braconnot, P., S. Joussaume, N. de Noblet, and G. Ramstein, 2000: Mid-Holocene and Last Glacial Maximum African monsoon changes as simulated within the Paleoclimate Modelling Intercomparison Project. Global Planet. Change, 26, 51-66, https://doi.org/10.1016/S0921-8181(00)00033-3.

_ , and Coauthors, 2007: Results of PMIP2 coupled simulations of the mid-Holocene and Last Glacial Maximum-Part 1: Experiments and large-scale features. Climate Past, 3, 261-277, https:// doi.org/10.5194/cp-3-261-2007.

— , S. P. Harrison, M. Kageyama, P. J. Bartlein, V. MassonDelmotte, A. Abe-Ouchi, B. Otto-Bliesner, and Y. Zhao, 2012a: Evaluation of climate models using palaeoclimatic data. Nat. Climate Change, 2, 417-424, https://doi.org/10.1038/ nclimate1456.

— Y. Y. Luan, S. Brewer, and W. Zheng, 2012b: Impact of Earth's orbit and freshwater fluxes on Holocene climate mean seasonal cycle and ENSO characteristics. Climate Dyn., 38, 10811092, https://doi.org/10.1007/s00382-011-1029-x.

Brown, J., M. Collins, A. W. Tudhope, and T. Toniazzo, 2008: Modelling mid-Holocene tropical climate and ENSO variability: Towards constraining predictions of future change with palaeo-data. Climate Dyn., 30, 19-36, https://doi.org/ 10.1007/s00382-007-0270-9.
Bush, A. B. G., 1999: Assessing the impact of mid-Holocene insolation on the atmosphere-ocean system. Geophys. Res. Lett., 26, 99-102, https://doi.org/10.1029/1998GL900261.

Chang, C. P., and T. Li, 2000: A theory for the tropical tropospheric biennial oscillation. J. Atmos. Sci., 57, 2209-2224, https://doi.org/ 10.1175/1520-0469(2000)057<2209:ATFTTT>2.0.CO;2.

Chiang, J., Y. Fang, and P. Chang, 2009: Pacific climate change and ENSO activity in the mid-Holocene. J. Climate, 22, 923-939, https://doi.org/10.1175/2008JCLI2644.1.

Clarke, A. J., and A. Lebedev, 1996: Long-term changes in the equatorial Pacific trade winds. J. Climate, 9, 1020-1029, https:// doi.org/10.1175/1520-0442(1996)009<1020:LTCITE>2.0.CO;2.

Clement, A. C., R. Seager, and M. A. Cane, 2000: Suppression of El Niño during the mid-Holocene by changes in the Earth's orbit. Paleoceanography, 15, 731-737, https://doi.org/10.1029/ 1999PA000466.

Compo, G. P., and Coauthors, 2011: The Twentieth Century Reanalysis Project. Quart. J. Roy. Meteor. Soc., 137, 1-28, https:// doi.org/10.1002/qj.776.

Dayem, K. E., D. C. Noone, and P. Molnar, 2007: Tropical western Pacific warm pool and Maritime Continent precipitation rates and their contrasting relationships with the Walker circulation. J. Geophys. Res., 112, D06101, https://doi.org/10.1029/2006JD007870.

Deser, C., and J. M. Wallace, 1990: Large-scale atmospheric circulation features of warm and cold episodes in the tropical Pacific. J. Climate, 3, 1254-1281, https://doi.org/10.1175/15200442(1990)003<1254:LSACFO>2.0.CO;2.

_ A. S. Phillips, and M. A. Alexander, 2010: Twentieth century tropical sea surface temperature trends revisited. Geophys. Res. Lett., 37, L10701, https://doi.org/10.1029/2010GL043321.

DiNezio, P. N., A. C. Clement, G. A. Vecchi, B. Soden, B. P. Kirtman, and S.-K. Lee, 2009: Climate response of the equatorial Pacific to global warming. J. Climate, 22, 4873 4892, https://doi.org/10.1175/2009JCLI2982.1.

$\longrightarrow,-$, and,- 2010 : Reconciling differing views of tropical Pacific climate change. Eos, Trans. Amer. Geophys. Union, 91 , 141-142, https://doi.org/10.1029/2010EO160001.

,,,-- B. Soden, A. J. Broccoli, B. L. Otto-Bliesner, and P. Braconnot, 2011: The response of the Walker circulation to Last Glacial Maximum forcing: Implications for detection in proxies. Paleoceanography, 26, PA3217, https://doi.org/ 10.1029/2010PA002083.

— , G. A. Vecchi, and A. C. Clement, 2013: Detectability of changes in the Walker circulation in response to global warming. J. Climate, 26, 4038-4048, https://doi.org/10.1175/ JCLI-D-12-00531.1.

Gagan, M. K., L. K. Ayliffe, D. Hopley, J. A. Cali, G. E. Mortimer, J. Chappell, M. T. McCulloch, and M. J. Head, 1998: Temperature and surface-ocean water balance of the midHolocene tropical western Pacific. Science, 279, 1014-1018, https://doi.org/10.1126/science.279.5353.1014.

Gastineau, G., L. Li, and H. Le Treut, 2009: The Hadley and Walker circulation changes in global warming conditions described by idealized atmospheric simulations. J. Climate, 22 , 3993-4013, https://doi.org/10.1175/2009JCLI2794.1.

Harrison, S. P., J. E. Kutzbach, Z. Liu, P. J. Bartlein, B. OttoBliesner, D. Muhs, I. C. Prentice, and R. S. Thompson, 2003: Mid-Holocene climates of the Americas: A dynamical response to changed seasonality. Climate Dyn., 20, 663-688, https://doi.org/10.1007/s00382-002-0300-6.

Held, I. M., and B. J. Soden, 2006: Robust responses of the hydrological cycle to global warming. J. Climate, 19, 5686-5699, https://doi.org/10.1175/JCLI3990.1. 
Jiang, D., X. Lang, Z. Tian, and L. Ju, 2013: Mid-Holocene East Asian summer monsoon strengthening: Insights from Paleoclimate Modeling Intercomparison Project (PMIP) simulations. Palaeogeogr. Palaeoclimatol. Palaeoecol., 369, 422-429, https://doi.org/10.1016/j.palaeo.2012.11.007.

_ _ Z. Tian, and X. Lang, 2015: Mid-Holocene global monsoon area and precipitation from PMIP simulations. Climate Dyn., 44, 2493-2512, https://doi.org/10.1007/s00382-014-2175-8.

Joussaume, S., and K. E. Taylor, 1995: Status of the Paleoclimate Modeling Intercomparison Project (PMIP). Proceedings of the First International AMIP Scientific Conference, W. L. Gates, Ed., WCRP-92, WMO/TD-732, 425-430.

- , and Coauthors, 1999: Monsoon changes for 6000 years ago: Results of 18 simulations from the Paleoclimate Modeling Intercomparison Project (PMIP). Geophys. Res. Lett., 26, 859862, https://doi.org/10.1029/1999GL900126.

Julian, P. R., and R. M. Chervin, 1978: A study of the Southern Oscillation and the Walker circulation phenomenon. Mon Wea. Rev., 106, 1433-1451, https://doi.org/10.1175/1520-0493 (1978)106<1433:ASOTSO > 2.0.CO;2.

Kitoh, A., and S. Murakami, 2002: Tropical Pacific climate at the mid-Holocene and the Last Glacial Maximum simulated by a coupled ocean-atmosphere general circulation model. Paleoceanography, 17, 1047, https://doi.org/10.1029/2001PA000724.

Knutson, T. R., and S. Manabe, 1995: Time-mean response over the tropical Pacific to increased $\mathrm{CO}_{2}$ in a coupled oceanatmosphere model. J. Climate, $\mathbf{8}, 2181-2199$, https://doi.org/ 10.1175/1520-0442(1995)008<2181:TMROTT >2.0.CO;2.

Kociuba, G., and S. B. Power, 2015: Inability of CMIP5 models to simulate recent strengthening of the Walker circulation: Implications for projections. J. Climate, 28, 20-35, https://doi.org/ 10.1175/JCLI-D-13-00752.1.

Koutavas, A., J. Lynch-Stieglitz, T. M. Marchitto, and J. P. Sachs, 2002: El Niño-like pattern in ice age tropical Pacific sea surface temperature. Science, 297, 226-230, https://doi.org/ 10.1126/science. 1072376 .

Krishnamurti, T. N., 1971: Tropical east-west circulations during the northern summer. J. Atmos. Sci., 28, 1342-1347, https://doi.org/ 10.1175/1520-0469(1971)028<1342:TEWCDT>2.0.CO;2.

—, M. Kanamitsu, W. J. Koss, and J. D. Lee, 1973: Tropical eastwest circulations during the northern winter. J. Atmos. Sci., 30, 780-787, https://doi.org/10.1175/1520-0469(1973)030<0780: TECDTN $>2.0 . \mathrm{CO} ; 2$

Kutzbach, J. E., and Z. Liu, 1997: Response of the African monsoon to orbital forcing and ocean feedbacks in the middle Holocene. Science, 278, 440-443, https://doi.org/10.1126/ science.278.5337.440.

Lea, D. W., D. K. Pak, C. L. Belanger, H. J. Spero, M. A. Hall, and N. J. Shackleton, 2006: Paleoclimate history of Galápagos surface waters over the last 135,000 yr. Quat. Sci. Rev., 25, 1152-1167, https://doi.org/10.1016/j.quascirev.2005.11.010.

L'Heureux, M. L., S. Lee, and B. Lyon, 2013: Recent multidecadal strengthening of the Walker circulation across the tropical Pacific. Nat. Climate Change, 3, 571-576, https://doi.org/ 10.1038/nclimate1840.

Li, T., L. Zhang, and H. Murakami, 2015: Strengthening of the Walker circulation under global warming in an aqua-planet general circulation model simulation. Adv. Atmos. Sci., 32, 1473-1480, https://doi.org/10.1007/s00376-015-5033-7.

Liu, J., B. Wang, M. A. Cane, S.-Y. Yim, and J.-Y. Lee, 2013: Divergent global precipitation changes induced by natural versus anthropogenic forcing. Nature, 493, 656-659, https://doi.org/ 10.1038/nature11784.
Liu, Z., J. Kutzbach, and L. Wu, 2000: Modeling climate shift of El Niño variability in the Holocene. Geophys. Res. Lett., 27, 2265-2268, https://doi.org/10.1029/2000GL011452.

Luo, J. J., W. Sasaki, and Y. Masumoto, 2012: Indian Ocean warming modulates Pacific climate change. Proc. Natl. Acad. Sci. USA, 109, 18 701-18 706, https://doi.org/10.1073/ pnas.1210239109.

Ma, J., S.-P. Xie, and Y. Kosaka, 2012: Mechanisms for tropical tropospheric circulation change in response to global warming. J. Climate, 25, 2979-2994, https://doi.org/10.1175/ JCLI-D-11-00048.1.

Ma, S., and T. Zhou, 2016: Robust strengthening and westward shift of the tropical Pacific Walker circulation during 19792012: A comparison of 7 sets of reanalysis data and 26 CMIP5 models. J. Climate, 29, 3097-3118, https://doi.org/10.1175/ JCLI-D-15-0398.1.

McGregor, S., A. Timmermann, M. F. Stuecker, M. H. England, M. Merrifield, F.-F. Jin, and Y. Chikamoto, 2014: Recent Walker circulation strengthening and Pacific cooling amplified by Atlantic warming. Nat. Climate Change, 4, 888-892, https:// doi.org/10.1038/nclimate2330.

Meng, Q., M. Latif, W. Park, N. S. Keenlyside, V. A. Semenov, and T. Martin, 2012: Twentieth century Walker circulation change: Data analysis and model experiments. Climate Dyn., 38, 17571773, https://doi.org/10.1007/s00382-011-1047-8.

Otto-Bliesner, B. L., E. C. Brady, S.-I. Shin, Z. Liu, and C. Shields, 2003: Modeling El Niño and its tropical teleconnections during the last glacial-interglacial cycle. Geophys. Res. Lett., 30, 2198, https://doi.org/10.1029/2003GL018553.

Philander, S. G., 1990: El Niño, La Niña, and the Southern Oscillation. Academic Press, 293 pp.

Power, S. B., and G. Kociuba, 2011: What caused the observed twentieth-century weakening of the Walker circulation? J. Climate, 24, 6501-6514, https://doi.org/10.1175/2011JCLI4101.1.

Roberts, W. H. G., D. S. Battisti, and A. W. Tudhope, 2014: ENSO in the mid-Holocene according to CSM and HadCM3. J. Climate, 27, 1223-1242, https://doi.org/ 10.1175/JCLI-D-13-00251.1.

Roe, G. H., 2005: Orographic precipitation. Annu. Rev. Earth Planet. Sci., 33, 645-671, https://doi.org/10.1146/annurev. earth.33.092203.122541.

Sandeep, S., F. Stordal, P. D. Sardeshmukh, and G. P. Compo, 2014: Pacific Walker circulation variability in coupled and uncoupled climate models. Climate Dyn., 43, 103-117, https:// doi.org/10.1007/s00382-014-2135-3.

Sandweiss, D. H., J. B. Richardson, E. J. Reitz, H. B. Rollins, and K. A. Maasch, 1996: Geoarchaeological evidence from Peru for a 5000 year B.P. onset of El Niño. Science, 273, 1531-1533, https://doi.org/10.1126/science.273.5281.1531.

Schwendike, J., P. Govekar, M. J. Reeder, R. Wardle, G. J. Berry, and C. Jakob, 2014: Local partitioning of the overturning circulation in the tropics and the connection to the Hadley and Walker circulations. J. Geophys. Res. Atmos., 119, 1322-1339, doi:10.1002/2013JD020742.

Sobel, A. H., C. D. Burleyson, and S. E. Yuter, 2011: Rain on small tropical islands. J. Geophys. Res., 116, D08102, https://doi.org/ 10.1029/2010JD014695.

Sohn, B. J., and S.-C. Park, 2010: Strengthened tropical circulations in past three decades inferred from water vapor transport. J. Geophys. Res., 115, D15112, https://doi.org/10.1029/ 2009JD013713.

, S.-W. Yeh, J. Schmetz, and H.-J. Song, 2013: Observational evidences of Walker circulation change over the last 30 years 
contrasting with GCM results. Climate Dyn., 40, 1721-1732, https://doi.org/10.1007/s00382-012-1484-z.

Stott, L., K. Cannariato, R. Thunell, G. H. Haug, A. Koutavas, and S. Lund, 2004: Decline of surface temperature and salinity in the western tropical Pacific Ocean in the Holocene epoch. Nature, 431, 56-59, https://doi.org/10.1038/nature02903.

Tanaka, H. L., N. Ishizaki, and A. Kitoh, 2004: Trend and interannual variability of Walker, monsoon and Hadley circulations defined by velocity potential in the upper troposphere. Tellus, 56A, 250-269, https://doi.org/10.3402/ tellusa.v56i3.14410.

Taylor, K. E., R. J. Stouffer, and G. A. Meehl, 2012: An overview of CMIP5 and the experiment design. Bull. Amer. Meteor. Soc., 93, 485-498, https://doi.org/10.1175/BAMS-D-11-00094.1.

Tian, Z., T. Li, D. Jiang, and L. Chen, 2017: Causes of ENSO weakening during the mid-Holocene. J. Climate, 30, 70497070, https://doi.org/10.1175/JCLI-D-16-0899.1.

Timmermann, A., J. Sachs, and O. E. Timm, 2014: Assessing divergent SST behavior during the last 21 ka derived from alkenones and $G$. ruber $-\mathrm{Mg} / \mathrm{Ca}$ in the equatorial Pacific. Paleoceanography, 29, 680 696, https://doi.org/10.1002/2013PA002598.

Tokinaga, H., S.-P. Xie, A. Timmermann, S. McGregor, T. Ogata, H. Kubota, and Y. M. Okumura, 2012a: Regional patterns of tropical Indo-Pacific climate change: Evidence of the Walker circulation weakening. J. Climate, 25, 1689-1710, https://doi.org/ 10.1175/JCLI-D-11-00263.1.

C. Deser, Y. Kosaka, and Y. M. Okumura, 2012b: Slowdown of the Walker circulation driven by tropical IndoPacific warming. Nature, 491, 439-443, https://doi.org/10.1038/ nature11576.

Tudhope, A. W., and Coauthors, 2001: Variability in the El NiñoSouthern Oscillation through a glacial-interglacial cycle. Science, 291, 1511-1517, https://doi.org/10.1126/science.1057969.

Vecchi, G. A., and B. J. Soden, 2007: Global warming and the weakening of the tropical circulation. J. Climate, 20, 43164340, https://doi.org/10.1175/JCLI4258.1.

,-- A. T. Wittenberg, I. M. Held, A. Leetmaa, and M. J. Harrison, 2006: Weakening of tropical Pacific atmospheric circulation due to anthropogenic forcing. Nature, $\mathbf{4 4 1}$, 73-76, https://doi.org/10.1038/nature04744.

Wang, B., J. Liu, H.-J. Kim, P. J. Webster, and S.-Y. Yim, 2012: Recent change of the global monsoon precipitation (19792008). Climate Dyn., 39, 1123-1135, https://doi.org/10.1007/ s00382-011-1266-z.
Wang, H. J., 1999: Role of vegetation and soil in the Holocene megathermal climate over China. J. Geophys. Res., 104, 9361-9367, https://doi.org/10.1029/1999JD900049.

Webster, P. J., V. O. Magana, T. N. Palmer, J. Shukla, R. A. Tomas, M. Yanai, and T. Yasunari, 1998: Monsoons: Processes, predictability, and the prospects for prediction. J. Geophys. Res., 103, 14 451-14 510, https://doi.org/10.1029/97JC02719.

Wu, B., T. Zhou, and T. Li, 2009: Seasonally evolving dominant interannual variability modes of East Asian climate. J. Climate, 22, 2992-3005, https://doi.org/10.1175/2008JCLI2710.1.

$\mathrm{Yu}, \mathrm{B}$., and G. Boer, 2002: The roles of radiation and dynamical processes in the El Niño-like response to global warming. Climate Dyn., 19, 539-554, https://doi.org/10.1007/s00382-002-0244-x.

_ and F. W. Zwiers, 2010: Changes in equatorial atmospheric zonal circulations in recent decades. Geophys. Res. Lett., 37, L05701, doi:10.1029/2009GL042071.

,-- G. J. Boer, and M. F. Ting, 2012: Structure and variances of equatorial zonal circulation in a multimodel ensemble. Climate Dyn., 39, 2403-2419, https://doi.org/10.1007/ s00382-012-1372-6.

Zhang, M., and H. Song, 2006: Evidence of deceleration of atmospheric vertical overturning circulation over the tropical $\mathrm{Pa}$ cific. Geophys. Res. Lett., 33, L12701, https://doi.org/10.1029/ 2006 GL025942.

Zhao, Y., P. Braconnot, S. P. Harrison, P. Yiou, and O. Marti, 2007: Simulated changes in the relationship between tropical ocean temperatures and the western African monsoon during the mid-Holocene. Climate Dyn., 28, 533-551, https://doi.org/ 10.1007/s00382-006-0196-7.

Zheng, W., P. Braconnot, E. Guilyardi, U. Merkel, and Y. Yu, 2008: ENSO at $6 \mathrm{ka}$ and $21 \mathrm{ka}$ from ocean-atmosphere coupled model simulations. Climate Dyn., 30, 745-762, https://doi.org/ 10.1007/s00382-007-0320-3.

— B. Bu, J. He, and Y. Yu, 2013: The East Asian summer monsoon at mid-Holocene: Results from PMIP3 simulations. Climate Past, 9, 453-466, https://doi.org/10.5194/cp-9-453-2013.

Zhou, B., and P. Zhao, 2010: Modeling variations of summer upper tropospheric temperature and associated climate over the Asian Pacific region during the mid-Holocene. J. Geophys. Res., 115, D20109, https://doi.org/10.1029/2010JD014029.

_ and - 2013: Simulating changes of spring Asian-Pacific oscillation and associated atmospheric circulation in the midHolocene. Int. J. Climatol., 33, 529-538, https://doi.org/ 10.1002/joc. 3438 . 